\title{
Optimalisasi Pengelolaan dan Pemanfaatan Aset Tanah dan Bangunan Perguruan Tinggi Negeri (PTN) yang Melaksanakan Pengelolaan Keuangan Badan Layanan Umum (PK BLU) dalam Rangka Meningkatkan Pelayanan Pendidikan
}

\author{
Dewi Kania Sugiharti ${ }^{16}$
}

\begin{abstract}
Abstrak
Perguruan Tinggi Negeri Pengelolaan Keuangan Badan Layanan Umum (PTN-PK BLU) merupakan instansi pemerintah yang diberi kewenangan untuk melakukan pengelolaan keuangan badan layanan umum, dengan tujuan untuk meningkatkan pelayanan bidang pendidikan kepada masyarakat dalam rangka mencerdaskan kehidupan bangsa. Fleksibilitas dalam pengelolaan keuangan PTNPKBLU berdasarkan prinsip ekonomi dan produktivitas, serta penerapan praktik bisnis yang sehat. Berdasarkan PP Nomor 23 Tahun 2005 dan PP Nomor 6 Tahun 2006 sebagaimana telah diubah dengan PP Nomor 38 Tahun 2008, fleksibilitas tersebut hanya berlaku dalam pengelolaan keuangan. Tanah dan bangunan yang berada dalam penguasaan PTNPKBLU, wajib dipergunakan sesuai dengan tugas pokok dan fungsi PTNPKBLU tersebut. Secara normatif, tidak ada ketentuan yang memberikan wewenang kepada kuasa pengguna barang untuk memanfaatkannya untuk tujuan lain. Aturan memberi peluang untuk mendayagunakan barang milik negara yang tidak dipergunakan sesuai dengan tugas pokok dan fungsi, yaitu dalam bentuk sewa, pinjam pakai, kerja sama pemanfaatan, dan bangun serah guna/bangun guna serah dengan tidak mengubah status kepemilikan, namun pemanfaatan tersebut hanya dapat dilakukan oleh pengelola barang, bukan oleh kuasa pengguna barang. Dalam hal ini, kuasa pengguna barang milik negara hanya berwenang dan bertanggung jawab untuk menyerahkan tanah dan/atau bangunan yang tidak dimanfaatkan untuk kepentingan penyelenggaraan tugas pokok dan fungsi kantor yang dipimpinnya tersebut, kepada pengguna barang.
\end{abstract}

Kata Kunci: aset, bangunan, pengelolaan keuangan, perguruan tinggi negeri, tanah.

\section{Optimization on Management and Utilization of State University's Land and Building Assets which Perform Financial Management in Order to Upgrade Education Service}

\begin{abstract}
State University implementing $P K B L U$ is a government agency with the right to use Pengelolaan Keuangan Badan Layanan Umum (PK BLU) to better increase educational service in order to improve the intellectual life of the people of Indonesia. Flexibility in a State
\end{abstract}

16 Dosen Fakultas Hukum Universitas Padjadjaran, Jalan Dipati Ukur No. 35, Bandung, dewisyifa@yahoo.com, S.H., M.H., Dr. (Universitas Padjadjaran). 
Dewi Kania Sugiharti: Optimalisasi Pengelolaan dan Pemanfaatan Aset Tanah dan Bangunan Perguruan Tinggi Negeri (PTN) yang Melaksanakan Pengelolaan Keuangan Badan Layanan Umum (PK BLU) dalam Rangka Meningkatkan Pelayanan Pendidikan

University implementing PK BLU has to be based on economic principles, productivity, and fairness. Based on Government Regulation 23/2005 and Government Regulation 6/2006 amended by Government Regulation 38/2008, its flexibility applies only in financial management. Land and building in the possession of the State University PKBLU, are to be used in accordance with their designated tasks and functions. Normatively, there is no regulation that gives authority to the proxy of asset user to perform optimization beyond its designated purpose. Regulation gives opportunity to utilize state owned assets which are not used in accordance with the designated tasks and functions in forms lease, 'pinjam pakai', cooperative utilization, 'bangun serah guna'/'bangun guna serah' without ownership changing. However, the utilization could only be conducted by asset manager, not the proxy of asset user. The proxy asset user of state owned asset has only the right and responsibility to assign unused land and building for the interest of the asset users.

Keywords: asset, building, financial management, land, state university.

\section{A. Pendahuluan}

PK BLU didirikan dengan tujuan untuk meningkatkan pelayanan kepada masyarakat dalam rangka memajukan kesejahteraan umum dan mencerdaskan kehidupan bangsa dengan memberikan fleksibilitas dalam pengelolaan keuangan berdasarkan prinsip ekonomi, produktivitas, dan penerapan praktik bisnis yang sehat. ${ }^{1}$ PK BLU tidak ditujukan untuk mencari keuntungan sebagai prioritas utama, akan tetapi diperbolehkan untuk mencari keuntungan. ${ }^{2}$

Pertumbuhan jumlah PK BLU di Indonesia terus mengalami peningkatan dengan jumlah penetapan Satuan Kerja (Satker) yang bervariasi. Sampai dengan Mei 2013, terdapat 141 Satker yang telah ditetapkan untuk menerapkan PK BLU. ${ }^{3}$ Pada tahun 2005, terdapat 13 Satker yang ditetapkan menjadi PK BLU, 2006 sebanyak 4 Satker, 2007 sebanyak 20 Satker, 2008 sebanyak 16 Satker, 2009 sebanyak 28 Satker, 2010 sebanyak 24 Satker, 2011 sebanyak 21 Satker, dan tahun 2011 sebanyak 15 Satker. $^{4}$ Ditinjau dari perspektif bidang layanan, pendidikan merupakan bidang layanan terbesar yang dilaksanakan oleh PK BLU. Berdasarkan laporan dari Direktorat

1 Pasal 2 Peraturan Pemerintah Nomor 74 Tahun 2012 tentang Perubahan atas Peraturan Pemerintah Nomor 23 Tahun 2005 tentang Pengelolaan Keuangan Badan Layanan Umum (selanjutnya disebut Peraturan Pemerintah tentang PK BLU).

2 Arifin P. Soeriaatmadja, Keuangan Publik dalam PerspektifHukum, Jakarta: Rajawali Pers, 2009, hlm. 348.

3 Direktorat Pembinaan Pengelolaan Keuangan Badan Layanan Umum Direktorat Jenderal Perbendaharaan, "Satker yang Telah Ditetapkan untuk Menjadi PK BLU Per 27 Mei 2013", http://www.ppkblu.depkeu.go.id/index.php/halaman/30/satker-blu, diunduh pada 18 Oktober 2013.

4 Direktorat Pembinaan Pengelolaan Keuangan Badan Layanan Umum Direktorat Jenderal Perbendaharaan, "Data Satker BLU Berdasarkan Tahun Penetapan", http://www.ppkblu.depkeu.go.id/index.php/news/graph, diunduh pada 18 Oktober 2013. 
Dewi Kania Sugiharti: Optimalisasi Pengelolaan dan Pemanfaatan Aset Tanah dan Bangunan Perguruan Tinggi Negeri (PTN) yang Melaksanakan Pengelolaan Keuangan Badan Layanan Umum (PK BLU) dalam Rangka Meningkatkan Pelayanan Pendidikan

Pembinaan Pengelolaan Keuangan Badan Layanan Umum Direktorat Jenderal Perbendaharaan, layanan pendidikan yang dilakukan oleh PK BLU mencapai 60 Satker dari total satuan kerja PK BLU. ${ }^{5}$

Salah satu komponen dari PK BLU adalah pengelolaan atas tanah dan bangunan yang merupakan bagian dari pengelolaan barang. Pengelolaan tanah dan bangunan PK BLU akan berimplikasi terhadap status penggunaan tanah dan bangunan tersebut sehingga PK BLU dituntut untuk mengelola setiap tanah dan bangunan guna mencapai tujuan PK BLU. Terdapat dua implikasi terkait dengan tanah dan bangunan pada PK BLU, yaitu: Pertama, PK BLU tidak memiliki kewenangan secara mandiri untuk mengalihkan, memindahtangankan, dan/atau menghapus aset tetap, kecuali atas persetujuan yang dilakukan sesuai ketentuan peraturan perundang-undangan; ${ }^{6}$ Kedua, tanah dan bangunan yang tidak digunakan BLU untuk penyelenggaraan tugas pokok dan fungsinya dapat dialihgunakan oleh menteri/pimpinan lembaga/kepala SKPD terkait dengan persetujuan Menteri Keuangan/Gubernur/Bupati/Walikota sesuai dengan kewenangannya.

Selain itu, dalam tataran praktik, terdapat pimpinan PTN yang menerapkan PK BLU yang beranggapan bahwa penjualan aset berupa tanah dan bangunan merupakan solusi untuk meningkatkan layanan pendidikan, padahal hal tersebut tidak sejalan dengan kewenangan yang diatur dalam perundangan. Jika ditinjau dari pengaturan tentang PK BLU, PK BLU tidak memiliki kewenangan mandiri untuk melakukan pemindahtanganan tanah dan bangunan.

Berdasarkan latar belakang tersebut, maka dapat dirumuskan dua permasalahan, yaitu: Pertama, bagaimanakah pengaturan pengelolaan tanah dan bangunan PTN yang melaksanakan PK BLU; Kedua, upaya apakah yang dapat dilakukan oleh PTN yang melaksanakan PK BLU dalam rangka optimalisasi pengelolaan tanah dan bangunan guna meningkatkan pelayanan pendidikan. Kedua permasalahan tersebut akan dibahas secara komprehensif dengan tujuan, yaitu: Pertama, memberikan gambaran mengenai pengaturan tentang pengelolaan tanah dan bangunan pada instansi pemerintah yang melaksanakan PK BLU; Kedua, memberikan referensi atau rujukan dalam rangka menentukan langkah yang dapat dilakukan atas pengelolaan tanah dan bangunan pada PTN yang menerapkan PK BLU guna meningkatkan pelayanan pendidikan.

Spesifikasi penelitian yang digunakan dalam penelitian ini menggunakan metode deskriptif analitis. ${ }^{7}$ Penelitian dilakukan dengan memberikan gambaran secara

5 Direktorat Pembinaan Pengelolaan Keuangan Badan Layanan Umum Direktorat Jenderal Perbendaharaan, "Data Satker BLU Berdasarkan Rumpun",http://www.ppkblu.depkeu.go.id/index.php/news/graph, diunduh pada 18 Oktober 2013.

6 Pasal 22 ayat (1) Peraturan Pemerintah tentang PK BLU.

7 Soerjono Soekanto, Pengantar Penelitian Hukum, Jakarta: UI Press, 2006, hlm. 10. 
Dewi Kania Sugiharti: Optimalisasi Pengelolaan dan Pemanfaatan Aset Tanah dan Bangunan Perguruan Tinggi Negeri (PTN) yang Melaksanakan Pengelolaan Keuangan Badan Layanan Umum (PK BLU) dalam Rangka Meningkatkan Pelayanan Pendidikan

lengkap data terkait pengaturan tentang peningkatan pengelolaan dan pemanfaatan aset tanah dan bangunan untuk meningkatkan layanan pendidikan. Masalah yang diteliti dalam tulisan ini akan dikaji dengan menggunakan metode pendekatan yuridis normatif. Pendekatan yuridis normatif dilakukan dengan melakukan pengujian peraturan terkait dengan pengelolaan dan pemanfaatan aset tanah dan bangunan guna meningkatkan pelayanan pendidikan pada PTN yang menerapkan PK BLU.

\section{B. Keuangan Negara}

Keuangan (kurang kata negara, merupakan salah satu alat pendukung untuk melakukan berbagai pekerjaan yang harus dijalankan oleh pemerintah dalam rangka melayani masyarakat, yang saat ini disebut sebagai keuangan negara). Keuangan negara adalah semua hak dan kewajiban negara yang dapat dinilai dengan uang, serta segala sesuatu baik berupa uang, maupun berupa barang yang dapat dijadikan milik negara berhubung dengan pelaksanaan hak dan kewajiban tersebut. ${ }^{8}$

Berdasarkan rumusan Pasal 1 Undang-Undang Nomor 17 Tahun 2003 tentang Keuangan Negara, pengelolaan keuangan negara meliputi: ${ }^{9}$ (1) Pengelolaan moneter, hal ini dilakukan melalui serangkaian kebijakan di bidang moneter. Kebijakan moneter adalah kebijaksanaan yang dilakukan oleh pemerintah agar ada keseimbangan yang dinamis antara jumlah uang yang beredar dengan barang dan jasa yang tersedia di masyarakat; (2) Kebijakan fiskal, meliputi fungsi-fungsi pengelolaan kebijakan fiskal dan kerangka ekonomi makro, penganggaran, administrasi, perpajakan, administrasi kepabean, perbendaharaan, dan pengawasan keuangan. Kebijakan fiskal adalah kebijakan yang dilakukan pemerintah berkaitan dengan penerimaan (pendapatan) dan pengeluaran (belanja) pemerintah; (3) Pengelolaan keuangan negara, khusus untuk proses pengadaan barang kekayaan negara, yang termasuk pengeluaran negara telah diatur secara khusus dalam Peraturan Presiden Nomor 70 Tahun 2012 tentang Perubahan Kedua atas Peraturan Presiden Nomor 54 Tahun 2010 tentang Pengadaan Barang/Jasa Pemerintah.

Tujuan pengelolaan keuangan negara adalah menciptakan kesejahteraan umum, sehingga setiap aturan hukum dalam pengelolaan dan pertanggungjawaban keuangan negara (perbendaharaan negara) harus ditaati. ${ }^{10}$ Sementara itu, negara memperoleh keuangan negara dari berbagai sektor yang masuk sebagai pendapatan atau penerimaan yang merupakan sumber keuangan negara. Sumber keuangan negara yang tampak dalam anggaran pendapatan dan belanja negara (APBN), secara

8 Pasal 1 Undang-Undang No.17 Tahun 2003 tentang Keuangan Negara.

9 Adrian Sutedi, Hukum Keuangan Negara, Jakarta: Sinar Grafika, 2010, hlm. 122-123.

10 Muhammad Djafar Saidi, Hukum Keuangan Negara, Jakarta: Rajawali Pers, 2008, hlm. 12. 
Dewi Kania Sugiharti: Optimalisasi Pengelolaan dan Pemanfaatan Aset Tanah dan Bangunan Perguruan Tinggi Negeri (PTN) yang Melaksanakan Pengelolaan Keuangan Badan Layanan Umum (PK BLU) dalam Rangka Meningkatkan Pelayanan Pendidikan

garis besar terdiri dari tiga, yaitu yang berasal dari sektor pajak, sektor penerimaan negara bukan pajak dan hibah. Djafar Saidi memerinci sumber keuangan negara yang terdiri dari pajak negara, bea dan cukai, dan penerimaan negara bukan pajak. ${ }^{11}$

\section{Badan Layanan Umum Penyelenggara Jasa di Bidang Pendidikan}

Dalam Pasal 1 angka 1 Peraturan Pemerintah Nomor 74 Tahun 2012 tentang Perubahan atas Peraturan Pemerintah Nomor 23 Tahun 2005 tentang Pengelolaan Keuangan Badan Layanan Umum, dinyatakan bahwa pengertian Badan Layanan Umum (BLU) adalah instansi di lingkungan pemerintah yang dibentuk untuk memberikan pelayanan kepada masyarakat berupa penyediaan barang dan/atau jasa yang dijual tanpa mengutamakan mencari keuntungan dan dalam melakukan kegiatannya didasarkan pada prinsip efisiensi dan produktivitas. Penetapan sebuah instansi pemerintah menjadi BLU dilakukan dengan Surat Keputusan yang dikeluarkan oleh Menteri Keuangan, sehingga instansi tersebut dapat dinyatakan sebagai instansi yang melaksanakan pola pengelolaan keuangan dengan konsep BLU. ${ }^{12}$

BLU merupakan bagian yang tak terpisahkan dari kementerian negara, lembaga non-kementerian, atau lembaga negara yang menyelenggarakan pengelolaan keuangan negara secara mandiri. ${ }^{13}$ Konsep BLU sudah banyak digunakan pada beberapa instansi pemerintah yang memiliki andil untuk memberikan pelayanan bagi masyarakat di bidang kesehatan, pendidikan, dan lain-lain. Dalam Pasal 2 Peraturan Pemerintah tentang PK BLU, dinyatakan bahwa BLU bertujuan untuk meningkatkan pelayanan kepada masyarakat dalam rangka memajukan kesejahteraan umum dan mencerdaskan kehidupan bangsa dengan memberikan fleksibilitas dalam pengelolaan keuangan berdasarkan prinsip ekonomi dan produktivitas, dan penerapan praktik bisnis yang sehat. Oleh karena itu, PK BLU diterapkan pada lembaga pendidikan, yaitu pendidikan tinggi. Pendidikan tinggi merupakan salah satu jenjang pendidikan yang mencakup program diploma, sarjana, magister, doktor, dan profesi, serta spesialis, yang diselenggarakan oleh perguruan tinggi berdasarkan kebudayaan bangsa Indonesia. ${ }^{14}$ Terdapat tiga jenis pendidikan tinggi, yaitu pendidikan akademik, vokasi, dan pendidikan profesi. ${ }^{15}$

Penyelenggaraan pendidikan tinggi dilakukan oleh perguruan tinggi, baik negeri maupun swasta. PTN merupakan perguruan tinggi yang didirikan dan/atau

11 lbid.

12 Selanjutnya akan disebut sebagai PP PK BLU.

13 Muhammad Djafar Saidi, Loc.cit.

14 Pasal 1 angka 2 Undang-Undang Nomor 12 Tahun 2012 tentang Pendidikan Tinggi (selanjutnya disebut UU Pendidikan Tinggi).

15 Pasal 15-17 UU Pendidikan Tinggi. 
Dewi Kania Sugiharti: Optimalisasi Pengelolaan dan Pemanfaatan Aset Tanah dan Bangunan Perguruan Tinggi Negeri (PTN) yang Melaksanakan Pengelolaan Keuangan Badan Layanan Umum (PK BLU) dalam Rangka Meningkatkan Pelayanan Pendidikan

diselenggarakan oleh pemerintah, sedangkan perguruan tinggi swasta (PTS) merupakan perguruan tinggi yang didirikan dan/atau diselenggarakan oleh masyarakat dengan membentuk badan penyelenggara berbadan hukum yang berprinsip nirlaba dan wajib memperoleh izin menteri. Mengacu kepada Peraturan Pemerintah tentang PK BLU, maka perguruan tinggi yang menerapkan PK BLU adalah PTN.

\section{Pengaturan Pengelolaan Tanah dan Bangunan pada Perguruan Tinggi Negeri Badan Layanan Umum}

Penelitian ini difokuskan terhadap pengelolaan barang milik negara berupa tanah dan/atau bangunan Badan Layanan Umum. Berdasarkan Undang-Undang Nomor 1 Tahun 2004 tentang Perbendaharaan Negara (UU Perbendaharaan Negara), Barang Milik Negara adalah semua barang yang dibeli atau diperoleh atas beban APBN atau berasal dari perolehan lainnya yang sah. Sementara itu, pengertian Badan Layanan Umum sebagaimana dirumuskan dalam (UU Perbendaharaan Negara) adalah instansi di lingkungan pemerintah yang dibentuk untuk memberikan pelayanan kepada masyarakat berupa penyediaan barang dan/atau jasa yang dijual tanpa mengutamakan mencari keuntungan dan dalam melakukan kegiatannya didasarkan pada prinsip efisiensi dan produktivitas.

Berdasarkan Pasal 42 (UU Perbendaharaan Negara), ditetapkan bahwa Menteri Keuangan memiliki wewenang atributif untuk mengatur pengelolaan barang milik negara, sedangkan menteri lainnya, termasuk pimpinan lembaga sebagai Pengguna Barang bagi kementerian negara/lembaga yang dipimpinnya dan kepala kantor dalam lingkungan kementerian negara/lembaga, adalah Kuasa Pengguna Barang dalam lingkungan kantor yang bersangkutan. Selanjutnya, dalam ketentuan Pasal 45 ayat (1), ditegaskan tentang larangan pemindahtanganan barang milik negara yang diperlukan bagi penyelenggaraan tugas pemerintahan negara.

Tugas pemerintahan negara dilaksanakan oleh lembaga-lembaga negara, antara lain Presiden. Berdasarkan Pasal 4 ayat (1) UUD 1945, ditentukan bahwa Presiden Republik Indonesia memegang kekuasaan pemerintahan. Presiden dibantu oleh menteri-menteri negara yang masing-masing membidangi urusan tertentu dalam pemerintahan. Pengaturan lebih lanjut tentang urusan tertentu dalam pemerintahan terdapat dalam Undang-Undang Nomor 39 Tahun 2008 tentang Kementerian Negara (UU Kementerian) yang menentukan bahwa urusan tertentu dalam pemerintahan terdiri atas: ${ }^{16}(1)$ Urusan pemerintahan yang nomenklatur kementeriannya secara tegas disebutkan dalam UUD 1945, meliputi urusan luar negeri, dalam negeri, dan

16 Pasal 4 jo. Pasal 5 UU Kementerian. 
Dewi Kania Sugiharti: Optimalisasi Pengelolaan dan Pemanfaatan Aset Tanah dan Bangunan Perguruan Tinggi Negeri (PTN) yang Melaksanakan Pengelolaan Keuangan Badan Layanan Umum (PK BLU) dalam Rangka Meningkatkan Pelayanan Pendidikan

pertahanan; (2) Urusan pemerintahan yang ruang lingkupnya disebutkan dalam UUD 1945, meliputi urusan agama, hukum, keuangan, keamanan, hak asasi manusia, pendidikan, kebudayaan, kesehatan, sosial, ketenagakerjaan, industri, perdagangan, pertambangan, energi, pekerjaan umum, transmigrasi, transportasi, informasi, komunikasi, pertanian, perkebunan, kehutanan, peternakan, kelautan, dan perikanan; (3) Urusan pemerintahan dalam rangka penajaman, koordinasi, dan sinkronisasi program pemerintah, meliputi urusan perencanaan pembangunan nasional, aparatur negara, kesekretariatan negara, badan usaha milik negara, pertanahan, kependudukan, lingkungan hidup, ilmu pengetahuan, teknologi, investasi, koperasi, usaha kecil dan menengah, pariwisata, pemberdayaan perempuan, pemuda, olahraga, perumahan, dan pembangunan kawasan atau daerah tertinggal.

Urusan-urusan tersebut tidak selalu dilaksanakan oleh satu kementerian, bahkan dimungkinkan satu kementerian melaksanakan beberapa urusan, misalnya Menteri Pendidikan dan Kebudayaan (Mendikbud) sebagai pemimpin di Kementerian Pendidikan dan Kebudayaan (Kemendikbud), selain bertanggungjawab untuk mengurus masalah pendidikan dan kebudayaan, juga bertanggung jawab sebagai pengguna anggaran dan barang pada kementeriannya. Hal tersebut sejalan dengan ketentuan Pasal 8 UU Kementerian bahwa dalam melaksanakan tugasnya, kementerian menyelenggarakan fungsi antara lain sebagai pengelola barang milik atau kekayaan negara yang menjadi tanggung jawabnya.

Ketentuan Pasal 8 UU Kementerian tersebut sejalan dengan ketentuan Pasal 4 (UU Perbendaharaan Negara). Dengan demikian, Mendikbud sebagai pengguna anggaran/pengguna barang, memiliki wewenang: (1) menyusun dokumen pelaksanaan anggaran; (2) menunjuk Kuasa Pengguna Anggaran/Pengguna Barang; (3) menetapkan pejabat yang bertugas melakukan pemungutan penerimaan negara; (4) menetapkan pejabat yang bertugas melakukan pengelolaan utang dan piutang; (5) melakukan tindakan yang mengakibatkan pengeluaran anggaran belanja; (6) menetapkan pejabat yang bertugas melakukan pengujian dan perintah pembayaran; (7) menggunakan barang milik negara (8) menetapkan pejabat yang bertugas melakukan pengelolaan barang milik negara; (9) mengawasi pelaksanaan anggaran; (10) menyusun dan menyampaikan laporan keuangan. Salah satu organ yang berada di bawah Kemendikbud adalah PTN, baik yang berstatus sebagai satuan kerja, PK BLU, maupun Perguruan Tinggi Negeri Badan Hukum (PTNBH). Dalam UU Pendidikan Tinggi, dirinci secara jelas tata kelola dan kewenangan pengelolaan PTNBH. Hal ini berbeda dengan PTN PK BLU yang dalam UU Pendidikan Tinggi ditentukan bahwa PTN PK BLU memiliki tata kelola dan kewenangan pengelolaan sesuai dengan ketentuan peraturan perundang-undangan. Karena itu, PTN PK BLU berkorelasi dengan 
Dewi Kania Sugiharti: Optimalisasi Pengelolaan dan Pemanfaatan Aset Tanah dan Bangunan Perguruan Tinggi Negeri (PTN) yang Melaksanakan Pengelolaan Keuangan Badan Layanan Umum (PK BLU) dalam Rangka Meningkatkan Pelayanan Pendidikan

ketentuan Pasal 68 dan 69 (UU Perbendaharaan Negara) berikut peraturan pelaksanaannya, yaitu Peraturan Pemerintah Nomor 23 Tahun 2005 juncto Peraturan Pemerintah Nomor 74 Tahun 2012.

Sejalan dengan ketentuan Pasal 68 (UU Perbendaharaan Negara), PTN PK BLU yang berada di bawah Kemendikbud, memiliki karakteristik sebagai berikut : (1) dibentuk untuk meningkatkan pelayanan kepada masyarakat dalam rangka memajukan kesejahteraan umum dan mencerdaskan kehidupan bangsa; (2) kekayaannya merupakan kekayaan negara yang tidak dipisahkan serta dikelola dan dimanfaatkan sepenuhnya untuk menyelenggarakan kegiatan PTN PK BLU yang bersangkutan; (3) pembinaan keuangan dilakukan oleh Menteri Keuangan dan pembinaan teknis dilakukan oleh Mendikbud; (4) wajib menyusun rencana kerja dan anggaran tahunan; (5) rencana kerja dan anggaran serta laporan keuangan dan kinerjanya disusun dan disajikan sebagai bagian yang tidak terpisahkan dari rencana kerja dan anggaran serta laporan keuangan dan kinerja Kemendikbud; (6) pendapatan dan belanja dalam rencana kerja dan anggaran tahunan dikonsolidasikan dalam rencana kerja dan anggaran Kemendikbud; (7) pendapatan yang diperolehnya sehubungan dengan jasa layanan yang diberikan merupakan pendapatan negara; (8) dapat memperoleh hibah atau sumbangan dari masyarakat atau badan lain; (9) pendapatannya tersebut di atas dapat digunakan langsung untuk membiayai belanja PTN PK BLU yang bersangkutan.

Berkaitan dengan pengalihan aset tetap, baik dalam Peraturan Pemerintah Nomor 23 Tahun 2005, maupun Peraturan Pemerintah Nomor 74 Tahun 2012, terdapat larangan yang tegas mengenai pengalihan aset tetap BLU. Untuk lebih jelasnya, hal tersebut dapat dilihat pada tabel perbandingan pengaturan antara Peraturan Pemerintah Nomor 23 Tahun 2005 dengan Peraturan Pemerintah Nomor 74 Tahun 2012, sebagai berikut:

\section{Tabel}

Larangan Pengalihan Aset Tetap BLU

Pasal 22 Peraturan Pemerintah Nomor 23 Tahun 2005

(1) BLU tidak dapat mengalihkan dan/atau menghapus aset tetap, kecuali atas persetujuan pejabat yang berwenang.

\section{Pasal 22 Peraturan Pemerintah}

Nomor 74 Tahun 2012

(1) BLU tidak dapat mengalihkan, memindahtangankan, dan/atau menghapus aset tetap, kecuali atas persetujuan yang dilakukan sesuai ketentuan peraturan perundangundangan. 
Dewi Kania Sugiharti: Optimalisasi Pengelolaan dan Pemanfaatan Aset Tanah dan Bangunan Perguruan Tinggi Negeri (PTN) yang Melaksanakan Pengelolaan Keuangan Badan Layanan Umum (PK BLU) dalam Rangka Meningkatkan Pelayanan Pendidikan

(2) Kewenangan pengalihan dan/atau penghapusan aset tetap sebagaimana dimaksud pada ayat (1) diselenggarakan berdasarkan jenjang nilai dan jenis barang sesuai dengan ketentuan peraturan perundangundangan.
(2) Penerimaan hasil penjualan aset tetap sebagai akibat dari pemindahtanganan sebagaimana dimaksud pada ayat (1) diatur sebagai berikut:

a. Penerimaan hasil penjualan aset tetap yang pendanaannya berasal dari pendapatan BLU selain dari APBN/APBD merupakan pendapatan BLU dan dapat dikelola langsung untuk membiayai belanja BLU.

b. Penerimaan hasil penjualan aset tetap yang pendanaannya sebagian atau seluruhnya berasal dari APBN/APBD bukan merupakan pendapatan BLU dan wajib disetor ke rekening Kas Umum Negara/Daerah.

(3) Pengalihan, pemindahtanganan, dan/atau penghapusan aset tetap sebagaimana dimaksud pada ayat (1) dan ayat (2) dilaporkan kepada menteri/pimpinan lembaga/Kepala SKPD terkait.

(4) Pemanfaatan aset tetap untuk kegiatan yang tidak terkait atau tidak dalam rangka mendukung pelaksanaan tugas dan fungsi BLU harus mendapat persetujuan pejabat yang berwenang sesuai dengan ketentuan peraturan perundang-undangan.

(5) Ketentuan lebih lanjut mengenai pengelolaan aset BLU, diatur oleh MenteriKeuangan / Gubernur / Bupati / Walikota sesuai dengan kewenangannya.

Dari tabel tersebut, tampak jelas bahwa, baik dalam Peraturan Pemerintah Nomor 23 Tahun 2005, maupun dalam Peraturan Pemerintah Nomor 74 Tahun 2012, ditegaskan melarang untuk melakukan pengalihan/ pemindahtanganan/ 
Dewi Kania Sugiharti: Optimalisasi Pengelolaan dan Pemanfaatan Aset Tanah dan Bangunan Perguruan Tinggi Negeri (PTN) yang Melaksanakan Pengelolaan Keuangan Badan Layanan Umum (PK BLU) dalam Rangka Meningkatkan Pelayanan Pendidikan

penghapusan aset tetap BLU, kecuali atas persetujuan yang dilakukan sesuai ketentuan peraturan perundang-undangan. Larangan tersebut sejalan dengan ketentuan Pasal 45 ayat (1) Undang-Undang Nomor 1 Tahun 2004.

Berdasarkan Pasal 45 ayat (2) (UU Perbendaharaan Negara), pemindahtanganan barang milik negara dilakukan dengan cara: jual, dipertukarkan, dihibahkan, atau disertakan sebagai modal pemerintah setelah mendapat persetujuan DPR/DPRD. Sesuai dengan ketentuan Pasal 46 ayat (1), persetujuan DPR tersebut dilakukan untuk:

1. Pemindahtanganan tanah dan/atau bangunan, tetapi tidak termasuk tanah dan/atau bangunan yang:

a. Sudah tidak sesuai dengan tata ruang wilayah atau penataan kota;

b. Harus dihapuskan karena anggaran untuk bangunan pengganti sudah disediakan dalam dokumen pelaksanaan anggaran;

c. Diperuntukkan bagi pegawai negeri;

d. Diperuntukkan bagi kepentingan umum;

e. Dikuasai negara berdasarkan keputusan pengadilan yang telah memiliki kekuatan hukum tetap dan/atau berdasarkan ketentuan perundangundangan, yang jika status kepemilikannnya dipertahankan tidak layak secara ekonomis.

2. Pemindahtanganan barang milik negara selain tanah dan/atau bangunan yang bernilai lebih dari Rp100.000.000.000,00 (seratus miliar rupiah).

Sementara itu, pemindahtanganan barang milik negara selain tanah dan/atau bangunan yang bernilai lebih dari Rp10.000.000.000,00 (sepuluh miliar rupiah) sampai dengan Rp100.000.000.000,00 (seratus miliar rupiah) dilakukan setelah mendapat persetujuan Presiden, sedangkan pemindahtanganan barang milik negara selain tanah dan/atau bangunan yang bernilai sampai dengan Rp10.000.000.000,00 (sepuluh miliar rupiah) dilakukan setelah mendapat persetujuan Menteri Keuangan.

Mengacu pada ketentuan Pasal 49 (UU Perbendaharaan Negara), perlakuan terhadap barang milik negara adalah sebagai berikut:

1. Barang milik negara yang berupa tanah yang dikuasai Pemerintah Pusat harus disertifikatkan atas nama pemerintah Republik Indonesia;

2. Bangunan milik negara harus dilengkapi dengan bukti status kepemilikan dan ditatausahakan secara tertib;

3. Tanah dan bangunan milik negara yang tidak dimanfaatkan untuk kepentingan penyelenggaraan tugas pokok dan fungsi instansi yang bersangkutan, wajib diserahkan pemanfaatannya kepada Menteri Keuangan untuk kepentingan penyelenggaraan tugas pemerintahan negara; 
Dewi Kania Sugiharti: Optimalisasi Pengelolaan dan Pemanfaatan Aset Tanah dan Bangunan Perguruan Tinggi Negeri (PTN) yang Melaksanakan Pengelolaan Keuangan Badan Layanan Umum (PK BLU) dalam Rangka Meningkatkan Pelayanan Pendidikan

4. Barang milik negara dilarang untuk diserahkan kepada pihak lain sebagai pembayaran atas tagihan kepada Pemerintah Pusat;

5. Barang milik negara dilarang digadaikan atau dijadikan jaminan untuk mendapatkan pinjaman.

Secara normatif, pengaturan pengelolaan tanah dan bangunan pada PTN yang melaksanakan PTN PK BLU, secara rinci tidak terdapat pada Peraturan Pemerintah Nomor 23 Tahun 2005 juncto Peraturan Pemerintah Nomor 74 Tahun 2012, tetapi berlaku peraturan yang sama dengan PTN Satker dan instansi pemerintah lainnya, yakni diatur dalam (UU Perbendaharaan Negara) yang kemudian diatur lebih lanjut dalam Peraturan Pemerintah Nomor 6 Tahun 2006 sebagaimana telah diubah dengan Peraturan Pemerintah Nomor 38 Tahun 2008, yang kemudian pada tanggal 24 April 2014, pemerintah menerbitkan Peraturan Pemerintah Nomor 27 Tahun 2014 tentang Pengelolaan Barang Milik Negara/Daerah. Penggantian peraturan pemerintah tersebut disebabkan Peraturan Pemerintah Nomor 6 Tahun 2006 tentang Pengelolaan Barang Milik Negara/Daerah sebagaimana telah diubah dengan Peraturan Pemerintah Nomor 38 Tahun 2008 tentang Perubahan atas Peraturan Pemerintah Nomor 6 Tahun 2006 tentang Pengelolaan Barang Milik Negara/Daerah sudah tidak sesuai dengan perkembangan pengelolaan Barang Milik Negara/Daerah saat ini. ${ }^{17}$

\section{E. Upaya PTN PK BLU dalam Rangka Optimalisasi Pengelolaan Tanah dan Bangunan Guna Meningkatkan Pelayanan Pendidikan}

Dalam UUD 1945, dijamin hak setiap warga negara untuk mendapat pendidikan. Oleh karena itu, dalam UUD 1945 pun, dijamin ketersediaan dana untuk menyelenggarakan pendidikan tersebut sebagaimana ditentukan dalam Pasal 31 ayat (4) bahwa: "Negara memprioritaskan anggaran pendidikan sekurang-kurangnya dua puluh persen dari anggaran pendapatan dan belanja negara serta dari anggaran pendapatan dan belanja daerah untuk memenuhi kebutuhan penyelenggaraan pendidikan nasional". Sejalan dengan ketentuan tersebut, UU Pendidikan Tinggi mewajibkan PTN untuk:

"Mencari dan menjaring calon mahasiswa yang memiliki potensi akademik tinggi, tetapi kurang mampu secara ekonomi dan calon mahasiswa dari daerah terdepan, terluar, dan tertinggal untuk diterima paling sedikit $20 \%$ (dua puluh persen) dari seluruh mahasiswa baru yang diterima dan tersebar pada semua program studi".

17 Konsiderans menimbang Peraturan Pemerintah Nomor 27 Tahun 2014 tentang Pengelolaan Barang Milik Negara/Daerah, hurufb. 
Dewi Kania Sugiharti: Optimalisasi Pengelolaan dan Pemanfaatan Aset Tanah dan Bangunan Perguruan Tinggi Negeri (PTN) yang Melaksanakan Pengelolaan Keuangan Badan Layanan Umum (PK BLU) dalam Rangka Meningkatkan Pelayanan Pendidikan

Lebih tegas lagi, ditentukan dalam Pasal 76 UU Pendidikan Tinggi, bahwa pemerintah, pemerintah daerah, dan/atau perguruan tinggi berkewajiban memenuhi hak mahasiswa yang kurang mampu secara ekonomi untuk dapat menyelesaikan studinya sesuai dengan peraturan akademik. Hak-hak mahasiswa yang kurang mampu tersebut dapat berupa: (1) Beasiswa mahasiswa berprestasi; (2) Bantuan atau pembebasan biaya pendidikan; dan/atau (3) Pinjaman dana tanpa bunga yang wajib dilunasi setelah lulus dan/atau memperoleh pekerjaan. ${ }^{18}$

Di samping hal tersebut, berdasarkan UU Pendidikan Tinggi, juga diberikan keleluasaan kepada mahasiswa/orang tua atau penanggung jawab biaya pendidikan untuk membayar biaya pendidikan sesuai kemampuan ekonomi yang bersangkutan. Hal tersebut dimaksudkan supaya masyarakat Indonesia dapat menikmati pendidikan hingga pendidikan tinggi demi tercapainya tujuan mencerdaskan kehidupan bangsa, sebagai salah satu tujuan bernegara sebagaimana yang diamanatkan dalam Pembukaan UUD 1945.

Tercapainya kehidupan bangsa yang cerdas tersebut merupakan tanggung jawab pemerintah. Oleh karena itu, pemerintah berkewajiban mengalokasikan dana pendidikan dalam APBN, sehingga semua lapisan masyarakat memiliki peluang yang sama untuk mendapatkan pendidikan sampai jenjang tertinggi tanpa kendala kemampuan ekonomi.

Selain berasal dari pemerintah, pendanaan pendidikan tinggi dapat berasal dari orang tua mahasiswa yang mampu, juga dari masyarakat. Peran serta masyarakat dalam pendanaan pendidikan tinggi dapat berbentuk: ${ }^{19}$ hibah, wakaf, zakat, persembahan kasih, kolekte, dana punia, sumbangan individu dan/atau perusahaan, dana abadi pendidikan tinggi dan/atau, bentuk lain sesuai dengan peraturan perundang-undangan.

Pendanaan bagi penyelenggaraan pendidikan tinggi, dapat pula berasal dari hasil kerjasama pelaksanaan Tri Dharma Perguruan Tinggi yang bersangkutan. Bahkan, dalam UU Pendidikan Tinggi diatur tentang peran pemerintah untuk memfasilitasi dan memberikan insentif kepada dunia usaha dan dunia industri yang aktif memberikan bantuan dana atau sumbangan bagi penyelenggaraan pendidikan tinggi. ${ }^{20}$

Dari uraian di atas, tampak jelas bahwa semua lapisan masyarakat, baik golongan ekonomi kuat, menengah maupun lemah, berhak menempuh pendidikan tinggi sesuai kemampuan akademis masing-masing, dengan jaminan ketersediaan dana

18 Pasal 76 ayat (2) UU Pendidikan Tinggi.

19 Pasal 84 UU Pendidikan Tinggi.

20 Pasal 86 UU Pendidikan Tinggi. 
Dewi Kania Sugiharti: Optimalisasi Pengelolaan dan Pemanfaatan Aset Tanah dan Bangunan Perguruan Tinggi Negeri (PTN) yang Melaksanakan Pengelolaan Keuangan Badan Layanan Umum (PK BLU) dalam Rangka Meningkatkan Pelayanan Pendidikan

dari pemerintah. Dengan demikian, PTN PK BLU sebenarnya tidak perlu menjual atau memindahtangankan aset tanah dan/atau bangunan hanya untuk mendapatkan uang demi menyelenggarakan tugas Tri Dharma. Hal tersebut sejalan dengan ketentuan Pasal 87 UU Pendidikan Tinggi, bahwa Pemerintah dapat memberikan hak pengelolaan kekayaan negara kepada perguruan tinggi untuk kepentingan pengembangan pendidikan tinggi sesuai dengan ketentuan peraturan perundangundangan. Berdasarkan ketentuan Pasal 87 tersebut, pengelolaan aset tanah dan/atau bangunan oleh perguruan tinggi harus semata-mata digunakan untuk melaksanakan Tri Dharma yang menjadi tugas pokok dan fungsi perguruan tinggi, yang berlaku baik untuk PTN Satker, PTN PK BLU, maupun PTNBH, karena penggunaan untuk selain kepentingan Tri Dharma pada dasarnya dilarang. Penggunaan aset tanah dan/atau bangunan untuk selain tugas pokok dan fungsi PTN PK BLU, khususnya, harus dengan izin pejabat yang berwenang. Meskipun secara normatif diizinkan oleh pejabat yang berwenang untuk digunakan bagi tujuan lain, hasil penggunaannya harus masuk ke dalam kas negara, tidak akan masuk ke kas PTN PK BLU tersebut. Lagi pula, aset tanah yang dikuasai PTN harus disertifikatkan atas nama Pemerintah Republik Indonesia karena tanah dan bangunan tersebut adalah barang milik negara.

\section{F. Penutup}

Pengaturan pengelolaan tanah dan bangunan pada PTN yang melaksanakan PTN PK BLU, secara rinci tidak terdapat pada Peraturan Pemerintah Nomor 23 Tahun 2005 juncto Peraturan Pemerintah Nomor 74 Tahun 2012, tetapi berlaku peraturan yang sama dengan PTN Satker dan instansi pemerintah lainnya, yakni diatur dalam (UU Perbendaharaan Negara) yang kemudian diatur lebih lanjut dalam Peraturan Pemerintah Nomor 6 Tahun 2006 sebagaimana telah diubah dengan Peraturan Pemerintah Nomor 38 Tahun 2008, dan kemudian diganti dengan Peraturan Pemerintah Nomor 27 Tahun 2014 tentang Pengelolaan Barang Milik Negara/Daerah.

Tanah dan/atau bangunan yang berada dalam penguasaan PTN PK BLU, wajib dipergunakan sesuai dengan tugas pokok dan fungsi PTN PK BLU tersebut, karena secara normatif, tidak ada ketentuan yang memberi wewenang kepada Kuasa Pengguna Barang untuk memanfaatkannya untuk tujuan lain. Berdasarkan aturan yang berlaku untuk masalah tersebut, dimungkinkan untuk mendayagunakan barang milik negara yang tidak dipergunakan sesuai dengan tugas pokok dan fungsi dalam bentuk: sewa, pinjam pakai, kerja sama pemanfaatan, dan bangun serah guna/bangun guna serah dengan tidak mengubah status kepemilikan. Namun, pemanfaatan tersebut hanya dapat dilakukan oleh Pengelola Barang, bukan oleh Kuasa Pengguna Barang karena Kuasa Pengguna Barang Milik Negara hanya berwenang dan bertanggung jawab untuk menyerahkan tanah dan/atau bangunan 
Dewi Kania Sugiharti: Optimalisasi Pengelolaan dan Pemanfaatan Aset Tanah dan Bangunan Perguruan Tinggi Negeri (PTN) yang Melaksanakan Pengelolaan Keuangan Badan Layanan Umum (PK BLU) dalam Rangka Meningkatkan Pelayanan Pendidikan

yang tidak dimanfaatkan untuk kepentingan penyelenggaraan tugas pokok dan fungsi kantor yang dipimpinnya kepada pengguna barang.

Pemimpin PTN PK BLU yang berkedudukan sebagai Kuasa Pengguna Barang Milik Negara dalam mengelola dan memanfaatkan barang milik negara, khususnya yang menjadi objek kajian pengelolaan tanah dan bangunan, harus mematuhi semua ketentuan pengelolaan barang milik negara tersebut. Hal ini termasuk jika PTN PK BLU tersebut memiliki aset tanah dan/atau bangunan berlebih yang tidak digunakan untuk melaksanakan Tri Dharma Perguruan Tinggi, maka tidak perlu melakukan tindakan pengalihan/pemindahtanganan terhadap aset tesebut, karena jika pun hendak dilakukan harus mendapatkan persetujuan dari pejabat yang berwenang. Selain itu, uang hasil penjualan aset tersebut tidak akan masuk ke dalam kas PTN PK BLU, tetapi akan masuk ke dalam kas negara. Pemimpin PTN PK BLU sudah semestinya melakukan optimalisasi pemanfaatan aset tanah dan/atau bangunan semata-mata hanya untuk kepentingan Tri Dharma perguruan tinggi.

Berdasarkan ketentuan Pasal 6 ayat (2) Peraturan Pemerintah Nomor 27 Tahun 2014, Pengguna Barang memiliki wewenang dan tanggungjawab, antara lain :

a. menetapkan Kuasa Pengguna Barang dan menunjuk pejabat yang mengurus dan menyimpan Barang Milik Negara;

b. mengajukan rencana kebutuhan dan penganggaran Barang Milik Negara untuk Kementerian/Lembaga yang dipimpinnya;

c. melaksanakan pengadaan Barang Milik Negara sesuai dengan ketentuan peraturan perundang-undangan;

d. mengajukan permohonan penetapan status Penggunaan Barang Milik Negara yang berada dalam penguasaannya kepada Pengelola Barang;

e. menggunakan Barang Milik Negara yang berada dalam penguasaannya untuk kepentingan penyelenggaraan tugas dan fungsi Kementerian/ Lembaga;

f. mengamankan dan memelihara Barang Milik Negara yang berada dalam penguasaannya;

g. mengajukan usul Pemanfaatan Barang Milik Negara yang berada dalam penguasaannya kepada Pengelola Barang;

h. mengajukan usul Pemindahtanganan Barang Milik Negara yang berada dalam penguasaannya kepada Pengelola Barang;

i. menyerahkan Barang Milik Negara yang tidak digunakan untuk kepentingan penyelenggaraan tugas dan fungsi Kementerian/Lembaga yang dipimpinnya dan tidak dimanfaatkan oleh Pihak Lain kepada Pengelola Barang;

j. mengajukan usul Pemusnahan dan Penghapusan Barang Milik Negara yang berada dalam penguasaannya kepada Pengelola Barang;

k. melakukan pembinaan, pengawasan, dan pengendalian atas Penggunaan Barang Milik Negara yang berada dalam penguasaannya; 
Dewi Kania Sugiharti: Optimalisasi Pengelolaan dan Pemanfaatan Aset Tanah dan Bangunan Perguruan Tinggi Negeri (PTN) yang Melaksanakan Pengelolaan Keuangan Badan Layanan Umum (PK BLU) dalam Rangka Meningkatkan Pelayanan Pendidikan

I. melakukan pencatatan dan Inventarisasi Barang Milik Negara yang berada dalam penguasaannya; dan

m. menyusun dan menyampaikan laporan barang pengguna semesteran dan laporan barang pengguna tahunan yang berada dalam penguasaannya kepada Pengelola Barang.

Sementara itu, dalam Pasal 7 ayat (2), ditentukan bahwa Kuasa Pengguna Barang memiliki wewenang dan tanggung jawab :

a. mengajukan rencana kebutuhan Barang Milik Negara untuk lingkungan kantor yang dipimpinnya kepada Pengguna Barang;

b. mengajukan permohonan penetapan status Penggunaan Barang Milik Negara yang berada dalam penguasaannya kepada Pengguna Barang;

c. melakukan pencatatan dan Inventarisasi Barang Milik Negara yang berada dalam penguasaannya;

d. menggunakan Barang Milik Negara yang berada dalam penguasaannya untuk kepentingan penyelenggaraan tugas dan fungsi kantor yang dipimpinnya;

e. mengamankan dan memelihara Barang Milik Negara yang berada dalam penguasaannya;

f. mengajukan usul Pemanfaatan dan Pemindahtanganan Barang Milik Negara yang berada dalam penguasaannya kepada Pengguna Barang;

g. menyerahkan Barang Milik Negara yang tidak digunakan untuk kepentingan penyelenggaraan tugas dan fungsi kantor yang dipimpinnya dan sedang tidak dimanfaatkan Pihak Lain, kepada Pengguna Barang;

h. mengajukan usul Pemusnahan dan Penghapusan Barang Milik Negara yang berada dalam penguasaannya kepada Pengguna Barang;

i. melakukan pengawasan dan pengendalian atas Penggunaan Barang Milik Negara yang berada dalam penguasaannya; dan

j. menyusun dan menyampaikan laporan barang kuasa pengguna semesteran dan laporan barang kuasa pengguna tahunan yang berada dalam penguasaannya kepada Pengguna Barang.

\section{Daftar Pustaka}

\section{Buku}

Adrian Sutedi, Hukum Keuangan Negara, Sinar Grafika, Jakarta, 2010.

Arifin P. Soeriaatmadja, Penelitian Aspek-Aspek Hukum dalam Penyelesaian Piutang Negara, Badan Pembinaan Hukum Nasional Departemen Kehakiman, Jakarta, 1995. Keuangan Publik dalam Perspektif Hukum, Rajawali Pers,

Jakarta, 2009. 
Dewi Kania Sugiharti: Optimalisasi Pengelolaan dan Pemanfaatan Aset Tanah dan Bangunan Perguruan Tinggi Negeri (PTN) yang Melaksanakan Pengelolaan Keuangan Badan Layanan Umum (PK BLU) dalam Rangka Meningkatkan Pelayanan Pendidikan

Muhammad Djafar Saidi, Hukum Keuangan Negara, Rajawali Pers, Jakarta, 2008.

Riant Nugroho, Public Policy, PT. Elex Media Komputindo, Jakarta, 2009.

\section{Dokumen Hukum}

Undang-Undang Dasar Negara Republik Indonesia Tahun 1945.

Undang-Undang Nomor 17 Tahun 2003 tentang Keuangan Negara.

Undang-Undang Nomor 20 Tahun 2003 tentang Sistem Pendidikan Nasional.

Undang-Undang Nomor 1 Tahun 2004 tentang Perbendaharaan Negara.

Undang-Undang Nomor 15 Tahun 2004 tentang Pemeriksaan Pengelolaan dan

Tanggung Jawab Keuangan Negara.

Undang-undang Nomor 15 Tahun 2006 tentang Badan Pemeriksa Keuangan.

Peraturan Pemerintah Nomor 38 Tahun 2008 tentang Perubahan atas Peraturan

Pemerintah Nomor 6 Tahun 2006 tentang Pengelolaan Barang Milik Negara/Daerah.

Peraturan Pemerintah Nomor 66 Tahun 2010 tentang Perubahan atas Peraturan

Pemerintah Nomor 17 Tahun 2010 tentang Pengelolaan dan Penyelenggaraan Pendidikan.

Peraturan Pemerintah Nomor 74 Tahun 2012 tentang Perubahan atas Peraturan

Pemerintah Nomor 23 Tahun 2005 tentang Pengelolaan Keuangan Badan Layanan Umum.

Peraturan Pemerintah Nomor 27 Tahun 2014 tentang Pengelolaan Barang Milik Negara/Daerah. 